\title{
ADAPTATION TO EMERGENCY REMOTE TEACHING: PEDAGOGICAL STRATEGY FOR PRE-SERVICE LANGUAGE TEACHERS AMID COVID-19 PANDEMIC
}

\author{
Dr. Sumardi SUMARDI \\ ORCID: 0000-0002-9620-0650 \\ Faculty of Teacher Training and Education \\ Universitas Sebelas Maret \\ Surakarta, INDONESIA \\ Dr. Dyah NUGRAHANI \\ ORCID: 0000-0003-1063-9847 \\ Faculty of Language and Arts Education \\ Universitas PGRI Semarang \\ Semarang, INDONESIA
}

Received: 28/09/2020 Accepted: 27/10/2020

\begin{abstract}
Due to the COVID-19 pandemic, face-to-face instructions suspended; numerous campuses worldwide closed and were forced to initiate emergency remote teaching (ERT). Thus, this study explores an existing pedagogical strategy to adapt to ERT in the Indonesian context. The study focuses also on the challenges of implementing ERT-based instructions to promote students' engagement during instructional practices. The researcher made a case study in which YouTube, Zoom, and SPADA platforms were employed for ERT-based instructions at a university. Seventeen pre-service language teachers joining the microteaching course in which English as a medium of instruction were voluntarily recruited during the study. The results indicated that ERT-based instructions were praiseworthy as a successful instructional mode to cope with the suspension of face-to-face instructions. However, the prominent challenges were that the low-achieving students were typically lack of self-discipline to engage virtually during the class and teachers had limited control over such students. It is advocated that teachers are supposed to find out the effective instructional strategies to cope with students' negative learning attitude and to ensure that ERT-based instructions are effective for achieving learning objectives.
\end{abstract}

Keywords: COVID-19, emergency remote teaching, pre-service language teachers, pedagogical strategy.

\section{INTRODUCTION}

In early 2020, Indonesian education has been a period of uncertainty due to the COVID-19 pandemic. Face-to-face instructions were suspended; teachers and students were forced to adapt to the virtual-based instructions. Even, the closure of all levels of education ranging from elementary schools to universities is planned until the end of the year. Also, a survey by Alvara Research Center shows that 54.5 percent of respondents disagree to open the schools shortly because of the concern that students will be infected and carry the virus (2020). The survey suggests that the majority of people seek the students to continue studying from home to prevent the spread of COVID-19 and to protect them and teachers from exposure to the virus. Also, the Indonesian COVID-19 Task Force reports that until the mid of August 2020, the spread of COVID-19 in Indonesia continues to increase throughout the regions. More than a thousand people are confirmed positive for COVID-19 every day. This data imply that the face-to-face instructions cannot be carried out shortly and emergency remote teaching (ERT) is becoming the priority so that the students still have an access to education. ERT has been used in many countries, such as Palestine, Syria, Afghanistan, and the South of Africa (Affouneh et al, 2020) due to the political crisis, but it is completely novel in Indonesia. 
The nature of ERT-based instruction is different from that of online language instructions. The online language instruction has gained its popularity over the last decade with the growth of the internet and the proliferation of computer at home (Compton, 2009). However, the online language instructions do not run well amid the COVID-19 pandemic because of poor preparation and planning (Atmojo \& Nugroho, 2020). This suggests that online language instructions cannot be abruptly implemented without careful and intentional design and preparation (Hodges et al, 2020; Zuniga, 2020). The online language instructions prompted the need for new teaching approaches and teaching skills that are different from those used in faceto-face language instructions (Hampel \& Stickler, 2005). Grounded in the theories, it can be concluded that there are misconceptions related to what and how online language instruction is (Bozkurt \& Sharma, 2020). Not all virtual-based language instructions can be categorized as online language instructions if they are not prepared and designed carefully in advance from the very beginning of the semester. Therefore, what teachers might do is that they need to adapt to ERT into their language classroom. As such, ERT should not be labeled as online teaching considering the difference in educational approaches (Bozkurt \& Sharma, 2020).

Much research has already been carried out on the implementation of online instructions, both in language and non-language classes. It is reported that online learning helps the students in practicing language skills, acquiring new vocabularies, and improving their understanding of the contents of the lesson (Cakrawati, 2017); is very helpful amid the COVID-19 pandemic (Allo, 2020); and enhance learner motivation to communicate in the target language, promote autonomy and social presence (Kruck, 2012). Other studies also report that online instruction during the COVID-19 is flexible as teacher-student and student-student interaction are not restricted merely in the classroom (Andrade, 2015; Hodges et al, 2020; Martin \& Parker, 2014). Those studies provide new perspectives regarding the effectiveness of online instructions in language classrooms. Due to the rapid development of information technology, online language instructions are relatively easy to apply, both synchronously and asynchronously. In contrast, a few studies on ERT in language classrooms have been conducted. A research by Affouneh et al (2020) reports how to design an e-learning environment for emergency remote teaching in a coronavirus crisis. Moorhouse (2020a) researched in Hong Kong that aimed to describe the adaptations made to the initial teacher education course designed for face-to-face instruction that was required to be delivered online due to the COVID-19 pandemic. The latest was a research by Talidong (2020) to explore how Philippine teachers implement remote English language instruction. It was a research at primary schools and merely tried to identify teachers' perceptions of ERT and what considerations lead teachers to implement ERT in language classrooms. Grounded in those previous studies, no pieces of evidence on how pedagogical strategies are implemented during the implementation of ERT in language classes. An effective pedagogical strategy is an important factor to achieve predetermined instructional goals.

For this purpose, the subsidiary research questions are formulated as follows:

a. How is the existing language pedagogical strategy to adapt to emergency remote teaching (ERT) amid the COVID-19 pandemic?

b. What are the challenges of implementing ERT-based instruction to promote students' engagement during instructional practices?

\section{LITERATURE REVIEW}

Due to the temporary cessation of face-to-face instructions, many schools have tried hard to adapt to virtual language instructions by making use of information technology, including language instructional practices in many universities. In particular, the Ministry of Education and Culture mandated the schools and universities to provide alternative platforms for students to access education amid the COVID-19 pandemic. Instructional practices must keep continuing so that no students stop learning (2020). In a university context, this requires teacher educators to think of an alternative pedagogical strategy for pre-service language teachers to keep them served to complete their education in the remaining semester amid the COVID-19 pandemic. The abrupt changes allow teacher educators to move their instructional strategy from face-to-face to virtualbased instructions. The pedagogical strategy that was originally designed for face-to-face instructions must be adapted to virtual-based instructional practices. Wong and Moorhouse (2020) note that the process of adaptation is not easy due to the lack of knowledge on virtual instructions and what learning management 
system (LMS) is supposed to use. Furthermore, Hodges et al (2020) elucidate that teacher educators may not immediately be able to implement effective virtual teaching and learning because it requires careful design and planning. It implies that the virtual or online instructional system cannot necessarily be carried out by teacher educators without the pedagogical strategy that has been designed for this purpose in advance. In fact, teacher educators originally designed their pedagogical strategy for face-to-face instructions. Thus, they require to adapt the pedagogical strategy that is originally designed for face-to-face instructions to emergency remote teaching (ERT), rather than adapting it directly to the online instructional system.

\section{Online Teaching vs. Emergency Remote Teaching}

The differences between online teaching and ERT come from the idea of Hodges et al (2020) who clearly state that well-planned online learning experiences are meaningfully different from courses offered online in response to a crisis or disaster. Moreover, Bozkurt \& Sharma (2020) point out that online distance education is one thing and emergency remote teaching is another thing. The distinctive terminology of online teaching and ERT has been hotly debatable, but what should be noted is that ERT is not typically planned from the very beginning of the semester. It involves an abrupt shift from face-to-face language instructions into a remote in a view of the emergency crisis and it is supposed to go back to normal face-to-face instructions after the emergency is over (Hodges et al, 2020, Bozkurt \& Sharma, 2020) and it is different from online learning in a normal situation (Affouneh et al 2020). Online language teaching involves more than merely uploading educational content, rather, it is a learning process that provides learners agency, responsibility, flexibility, and choice (Bozkurt \& Sharma, 2020), but it needs complex preparation, such as careful planning, designing, and determination of instructional objectives to excogitate an effective instructional environment. That is why ERT is a temporary solution for language instructions and the quality of instructions might not be parallel to truly online instructions (Hodges et al, 2020). However, it enables the flexibility of language instruction anywhere and anytime.

To sum up, online language teaching is designed carefully in advance, but ERT is a temporary shift of instructional delivery to an alternate delivery mode due to crisis circumstances (Hodges et al 2020; Bozkurt \& Sharma, 2020; Manfuso, 2020; Shisley, 2020). The ERT-based instructional practice is not originally planned and designed for online teaching, but because of the particular crisis, such as the COVID-19 pandemic, natural disaster, political conflicts, etc., the practice of instructions is adapted online to provide access for education to students. It can be fully remote teaching as a solution for instruction or can be blended or hybrid courses. When the crisis has abated, the instructional practices will return to its original format, which is the face-to-face format of instruction.

\section{Pedagogical Strategy}

Owing to the COVID-19 pandemic, moving the face-to-face language instructions to ERT might increase the flexibility of teaching and learning anywhere and anytime. However, teacher educators are supposed to plan and design the pedagogical strategy carefully to provoke student teachers' engagement and interaction during the class. A pedagogical strategy can be defined as a set of procedures in learning, thinking, teaching, etc. that is used as a way to achieve a certain goal (Richards et al, 2001); it involves the teacher's capacity to design instructional scenarios adapted to distance that truly engage learners emotionally and cognitively (Guichon, 2009); and it is not easy to design online pedagogical strategy (Sun, 2011). What pedagogical teaching strategy a teacher educator is supposed to carry out involves a thoughtful design and planning (Orlich et al., 2010). A thoughtful design of a pedagogical strategy can be empowering the pre-service teachers or student teachers to become independent learners beyond the classroom and they are no longer passive recipients (Chambers, 2005). Furthermore, he advocates that to achieve an emerging pedagogical strategy that is powerful for student teachers to learn, the teacher educators are supposed to create extraordinary procedures or ways of teaching that are no longer teacher-centered pedagogy. It means that the pedagogical strategy designed by the teacher educators must be able to provoke the student teachers to learn independently. Moreover, the course contents, learning tasks and activities, group work, assessment - all of which resembles teaching in a teacher-driven environment and seldom goes beyond "automated learning 
resource delivery" (Palmer \& Holt, 2009). Besides, Sun (2011) advocates that online and ERT teacher educators must constantly review and reflect on their pedagogical strategy and remain committed to change.

\section{METHODOLOGY}

This is a case study that means research focuses on a single unit to produce an in-depth description that is rich and holistic (Ary, et al 2010). In addition, McMillan (2008) elucidates that a case study is an in-depth analysis of one or more events, settings, social groups, individuals, or communities that use qualitative methods to gather the data and obtain a detailed description. Specifically, this study aimed to explore an existing pedagogical strategy to adapt to ERT in an Indonesian context. The study also focused on identifying the challenges of implementing ERT-based instruction to promote students' engagement during instructional practices. The instructions were initially designed for face-to-face classroom and the social interactions were also in persons in the classroom. Due to the COVID-19 Pandemic, the teacher educator adapted the instructions to ERT with synchronous and asynchronous sessions offered as the solution for these issues. The learning management systems (LMS) adopted to implement ERT-based instructions were YouTube, Zoom, and SPADA.

\section{Participants}

This research involved 17 pre-service language teachers from a university in Indonesia who enrolled in the microteaching course in which English was used as a medium of instruction. They were $20-22$ years of age and fifteen of them were females, while the rest were males. Those preservice language teachers were recruited purposively on the basis of the following criteria: they were voluntarily willing to be included in this research; they have enrolled in the course that has been adapted to emergency remote teaching; and they had adequate knowledge on technology-supported teaching and learning.

\section{Data Collection and Analysis}

Fifteen questions were designed for an online survey on several points regarding the implementation of the pedagogical strategy adapted to emergency remote teaching amid the COVID-19 pandemic. The survey was then followed with the interviews with eight pre-service language teachers through a video conference system (VCS). To analyze the data acquired, the existing research used an interactive model of data analysis (Miles et al, 2014) with four fundamental stages, i.e. data collection, data condensation, data display, and drawing and verifying conclusion.

\section{Procedure}

The pre-service language teachers who joined the microteaching course were recruited voluntarily for the current study. The course was initially designed for face-to-face instructions. After it has been going on for four weeks, the instructions were shifted and adapted to ERT in which the pedagogical strategy was delivered by utilizing the instructional platforms, such as YouTube, Zoom, and SPADA. The ERT-based instructions followed a flipped-classroom approach (Santikarn \& Wichadee, 2018; Turan \& Akdag-Cimen, 2020) that involves class group discussion and engaging in online video lessons and assignment that must be completed additionally outside of the class time.

Adapted from Moorhouse (2020b), the pedagogical strategy entails of four stages, i.e. (1) providing input to the course contents; (2) checking pre-service language teachers' understanding/providing practice in the subject area; (3) analyzing pre-service language teachers' understanding, development and areas for improvement; and (4) providing feedback to the pre-service language teachers on understanding, development, and areas for improvement. To make it clear, the practices and instructional sequence are presented in table 1. 
Table 1. Practices and instructional sequence

\begin{tabular}{|c|c|c|c|}
\hline Stages & Instructional Approach & Pedagogical Strategy & $\begin{array}{l}\text { Activities and Digital Technologies } \\
\text { Utilized }\end{array}$ \\
\hline 1. & Tailor-made video & $\begin{array}{l}\text { Providing input to the course } \\
\text { contents }\end{array}$ & $\begin{array}{l}\text { The input was in the form of a } \\
\text { YouTube video depicting the } \\
\text { practices of English language } \\
\text { microteaching. The pre-service } \\
\text { language teachers scrutinized the } \\
\text { video to understand the eight basic } \\
\text { skills of teaching English they are } \\
\text { supposed to master. }\end{array}$ \\
\hline 2. & Post-viewing activity / exercise & $\begin{array}{l}\text { Checking the pre-service } \\
\text { language teachers' } \\
\text { understanding/providing } \\
\text { practices in the subject area }\end{array}$ & $\begin{array}{l}\text { The pre-service language teachers } \\
\text { discussed asynchronously the } \\
\text { contents of the video by uploading } \\
\text { their written ideas on the SPADA } \\
\text { wall. }\end{array}$ \\
\hline 3. & $\begin{array}{l}\text { Analyzing the pre-service } \\
\text { language teachers' responses }\end{array}$ & $\begin{array}{l}\text { Analyzing the pre-service } \\
\text { language teachers' } \\
\text { understanding, development, } \\
\text { and areas for improvement }\end{array}$ & $\begin{array}{l}\text { The teacher educator analyzed } \\
\text { the pre-service language teachers' } \\
\text { understanding, development, } \\
\text { and areas for improvement by } \\
\text { scrutinizing the variety of ideas the } \\
\text { students uploaded on the SPADA } \\
\text { wall. }\end{array}$ \\
\hline 4. & Individual/class feedback & $\begin{array}{l}\text { Providing feedback to the pre- } \\
\text { service language teachers on } \\
\text { understanding, development, } \\
\text { and areas for improvement }\end{array}$ & $\begin{array}{l}\text { The teacher educator provided any } \\
\text { feedback to the pre-service language } \\
\text { teachers on understanding, } \\
\text { development, and areas for } \\
\text { improvement synchronously by } \\
\text { leveraging Zoom as a platform of } \\
\text { instruction. }\end{array}$ \\
\hline
\end{tabular}

The digital technologies used for every single stage were different from one another. Firstly, YouTube was used to provide the pre-service language teachers input to the course contents. The input was in the form of a video depicting the practice of English language microteaching. Secondly, the pre-service language teachers discussed asynchronously the contents of the video by uploading their written ideas on the SPADA wall. Each pre-service language teacher then commented on the ideas uploaded by their peers. Thirdly, the teacher educator analyzed the pre-service language teachers' understanding, development, and areas for improvement by scrutinizing the variety of ideas the pre-service language teachers uploaded on the SPADA wall. Lastly, the teacher educator provided any feedback to the pre-service language teachers on understanding, development, and areas for improvement synchronously by leveraging Zoom as a platform of instruction.

\section{FINDINGS}

In the current research, ERT was implemented in the microteaching class in a university in which English was used as a medium of instruction. YouTube, Zoom, and SPADA were three different platforms used to deliver the course contents; platforms with which synchronous and asynchronous instructions and discussions were designed; platforms in which engagements and interactions were managed by the teacher educator and the pre-service language teachers; platforms in which assignment were supposed to submit by the pre-service language teachers; and platforms through which individual and classical feedback were provided by the teacher educator. Then, the researcher sought the consent of the pre-service language teachers to respond to the online survey on the implementation of an existing pedagogical strategy to adapt to ERT and what challenges were likely to emerge in terms of its implementation to promote the pre-service language teachers' engagement during instructional practices. 


\section{Participants' Responses to an Existing Pedagogical Strategy to Adapt to ERT}

The majority of pre-service language teachers were optimistic that an existing pedagogical strategy to adapt to ERT was beneficial to implement amid the COVID-19 pandemic. The online survey results on this perception are presented in the percentages; and they are followed by the data taken from interviews to ensure that they were consistent.

Table 2. Participants' responses to an existing pedagogical strategy to adapt to ERT

\begin{tabular}{|c|c|c|}
\hline Statements & Yes & No \\
\hline $\begin{array}{l}\text { I assume that the existing pedagogical strategy to adapt to ERT is beneficial to implement amid the } \\
\text { COVID-19 pandemic }\end{array}$ & $92 \%$ & $8 \%$ \\
\hline I believe that a well-planned ERT allows the instructional practices to achieve the predetermined goals & $97 \%$ & $3 \%$ \\
\hline I get some difficulties to attend the ERT-based instructions & $27 \%$ & $73 \%$ \\
\hline \multicolumn{3}{|l|}{ If you get difficulties to attend ERT-based instructions, which of the following causes } \\
\hline \multicolumn{3}{|l|}{ you to get such difficulties: } \\
\hline a. Unstable internet connection & $70 \%$ & \\
\hline $\begin{array}{l}\text { b. Technical problems, such as inadequate technological devices, outdated technological } \\
\text { devices, etc. }\end{array}$ & $9 \%$ & \\
\hline c. Overloading of online courses to attend & $14 \%$ & \\
\hline d. The passive pre-service language teachers & $7 \%$ & \\
\hline \multicolumn{3}{|l|}{ When ERT-based instructions are carried out, which platform of instruction do you like best: } \\
\hline a. Zoom & $92 \%$ & \\
\hline b. SPADA & $8 \%$ & \\
\hline \multicolumn{3}{|l|}{$\begin{array}{l}\text { If you do not like one of those platforms (Zoom/SPADA*) for mediating ERT-based instruction, } \\
\text { why: }\end{array}$} \\
\hline a. It is relatively hard for synchronous engagement and interaction & $86 \%$ & \\
\hline b. I am not highly familiar with the features of this platform & $12 \%$ & \\
\hline c. The features in this platform are less operational & $2 \%$ & \\
\hline \multicolumn{3}{|l|}{ If synchronous instructions are implemented, how long should the instructional practices last? } \\
\hline a. $30-50$ minutes & $72 \%$ & \\
\hline b. $51-100$ minutes & $28 \%$ & \\
\hline
\end{tabular}

*please cross the unnecessary one

The pre-service language teachers' perceptual descriptions about an existing pedagogical strategy to adapt to ERT were generally positive. They assumed mostly that this pedagogical strategy was manageable, and few of them assumed otherwise. However, they noted that it was manageable if the internet network was always in stable conditions and teachers possessed good creativity and ability to take advantage of a variety of instructional platforms, such as Zoom, Google meet, SPADA, YouTube, and many others. Lack of teacher's knowledge and skills to operate those various instructional platforms have resulted in the instructional practices being ineffective and unattractive. Nevertheless, they were still several participants got some difficulties to attend the ERT-based instructions, although most of the participants did not get any difficulties. This was because of the problems they had in ERT-based instructions, such as highly unstable internet connection; overloading of online courses to attend; technical problems such as inadequate technological devices, outdated technological devices, etc.; and passive pre-service language teachers. The instability of the internet network was due to the fact that they had to pay more to buy internet quota and some of them live in the blank spot areas. They required that the ERT-based instruction schedules did not collide with other courses. There needs to be good coordination among the teacher educators in arranging the schedules so as not to burden the pre-service language teachers. 
Concerning what platforms to use for ERT, Zoom was a primary choice to carry out ERT in the class in which English is used as a medium of instruction. Almost all of the pre-service language teachers chose Zoom as a platform of instruction, and very few of them chose SPADA as an instructional platform. The reason why Zoom was to be the best choice is that Zoom facilitates easily students' interactions and engagements during the class. They could interact directly with their teacher educators and their peers so that when they had some difficulties in terms of the course contents, they could easily seek their teacher educator to clarify them out and to receive direct responses. In addition, they could also be actively engaged during instructional practices. SPADA was not popular among the pre-service language teachers due to its inflexibilities. The majority of pre-service language teachers stated that SPADA was relatively hard for synchronous engagement and interaction; some of them stated that they were not highly familiar with any features in SPADA; and very few of them stated the features in SPADA were less operational. Since YouTube was exclusively used to provide input on microteaching practices and was not used too much during ERT, the pre-service language teachers' views on this platform were not widely explored.

In this current study, ERT was designed to follow a flipped-classroom approach in which the pre-service language teachers were initially introduced to a variety of instructional techniques through videos to scrutinize offline. Next, the synchronous discussions were carried out using Zoom as an instructional platform. It means that the instructional practices were carried out online, both synchronously and asynchronously. The duration of asynchronous instructions was designed to be longer than that of synchronous ones. This is in line with the choice of pre-service language teachers who preferred mostly synchronous instructions which are designed for a shorter time. Therefore, pre-service teachers consider that $30-50$ minutes was more appropriate to carry out synchronous classes. Some of them chose $51-100$ minutes. There were two main reasons why they did not want to stick to the synchronous instruction for too long. Firstly, they were scheduled to take the other courses synchronously as well, so they had to prepare themselves for other courses. Secondly, they believed that staring at too long to the computer screen or smartphone might result in a lot of radiation which causes a person to feel dizzy and have headaches.

A successful ERT depends much on the quality of teacher educators. Preparation is an important stage the teacher educators are supposed to execute before ERT-based instructions are carried out. Without proper preparation, instructional practices might not run smoothly. Moreover, the pre-service language teachers highly believed that a well-planned ERT allowed the instructional practices to achieve the predetermined goals; and very few of them did not observe such practices. Furthermore, they believed that there were supposed to adequate supports through systematic workshops from the institution to equip teacher educators with the skills to run technology for instruction. ERT is something new today and teacher educators are not frequently ready to encounter these abrupt changes due to the COVID-19 pandemic.

\section{The Challenges of Implementing ERT-Based Instructions}

The quality of engagement and interaction is a significant determinant to establish the success of the instructional practices to achieve the predetermined goals. Therefore, it is important to get the pre-service language teachers to engage and interact actively during the implementation of ERT in which English is used as a medium of instruction. The online survey results on these issues are presented in the percentages and they are strengthened with the interview results to ensure that the data were consistent. The interview was also intended to dig deeper related to the pre-service language teachers' perceptions of this issue.

Table 3. The challenges of implementing ERT-based instructions

\begin{tabular}{lcc}
\hline Statements & Yes & No \\
\hline $\begin{array}{l}\text { I believe that ERT has been able to facilitate the students to actively engage and interact during the } \\
\text { class }\end{array}$ & $82 \%$ & $18 \%$ \\
\hline $\begin{array}{l}\text { I opt to participate more actively in classroom activities rather than virtual activities } \\
\text { I am sure that it is possible to assess students' performance in the ERT class }\end{array}$ & $78 \% 22 \%$ \\
\hline $\begin{array}{l}\text { l occasionally get some difficulties to understand the course contents delivered by the teacher } \\
\text { virtually }\end{array}$ & $84 \%$ & $16 \%$ \\
\hline
\end{tabular}


Specifically, the pre-service language teachers mainly stated that ERT has been able to facilitate them to actively engage and interact during the class. They had no significant obstacles to engage and interact actively during the class. They were well-motivated to participate in ERT as they had to prepare themselves for the next semester's teaching internship. Also, they had no significant obstacles with the internet network so that they could participate in ERT properly. There were only small parts of the pre-service language teachers who could not engage and interact well. No specific reasons why they could not do so, but it should be suspected that this is due to their lower discipline and motivation to learn. Unfortunately, most of the pre-service language teachers reported themselves that they actually opted to participate more actively in the classroom activities; and some of them opted otherwise. On the other hand, the pre-service language teachers claimed that assessing learners' performance is possible in ERT class, while a few of them asserted the opposite. The assessment could be carried out in ERT-based instructions as well, although this assessment required that it be carried out online. However, they argued that to avoid the cheating that the students might commit, the test items should not allow the students to rely solely on their ability to remember and understand the course contents to answer the test items. The test items must require the students to use their ability to think critically and logically to respond to all the test items.

Having the pre-service language teachers all come to the virtual classroom at the same time was a tough challenge during the implementation of ERT. Some of them did not participate consistently during instructional practices. They were identified as low-achieving students having a lack of discipline to actively engage when the class is in progress. In addition, the prominent challenges were that the students occasionally got some difficulties to understand the course contents delivered by the teacher educator virtually. Nearly half of the pre-service language teachers sometimes had difficulties to grasp the course contents and teacher's explanation. The problems were due to the loss of lip synchronization and verbal clues, time lags, poor sound, and images. It happened very often so that the pre-service language teachers were frustrated during a virtual classroom.

\section{DISCUSSION}

The current study emphasizes more on exploring an existing pedagogical strategy to adapt to ERT and the challenges of implementing ERT-based instruction to promote students' engagement during instructional practices. The current ERT is specifically implemented in response to the COVID-19 pandemic. It is different from that of online teaching or instruction that is typically planned and designed carefully in advance from the very beginning of the semester. It means that the quality of ERT-based instructions could be different from that of the quality of truly online instructions. For the current study, ERT-based instruction has successfully been executed to cope with the suspension of the face-to-face classroom due to the COVID-19 pandemic. Grounded in the flipped-classroom approach, the pedagogical strategy makes the pre-service language teachers engage and interact effectively during the class. However, the prominent challenges are supposed to take into account by the teacher educator to make ERT run well. Therefore, the entire discussions are based on those pivotal issues.

Adaptation to ERT-based instruction can be a significant and quick solution in response to the current crisis of COVID-19 pandemic worldwide. Due to the COVID-19 pandemic, face-to-face instructions cannot find their ways and they are supposed to suspend until the crisis is over. That is why that ERT is beneficial when the teacher educator and the pre-service language teachers cannot find a day and time for having face-to-face instructions (Sun, 2020; Bozkurt \& Sharma, 2020). ERT is a flexible teaching and learning approach to apply during the COVID-19 pandemic because it enables the pre-service language teachers to access education without time and space restrictions. The pre-service language teachers can communicate with the teacher educator and their peers even though they are not in the same place. This suggests that the instructional practices can be still ongoing even though the COVID-19 crisis is hitting and disrupting their direct interactions in the classroom. Moreover, Hodges et al (2020) emphasize that moving instructions into ERT enables the flexibility of teaching and learning anywhere and anytime, although the impacts with which this move expected to happen are staggering. However, to get the staggering impacts of this adaptation to ERT, teacher educators need to possess adequate knowledge and skills concerning the digital technology utilized to design an appropriate pedagogical strategy. 
Because of the COVID-19 pandemic, many universities encounter decisions about how to keep continuing the instructional practices while they keep their faculty, staff, and students safe from a health emergency that is changing fast and poorly understood. Therefore, those universities opted to suspend all face-to-face instructions and mandated teacher educators to change their courses into ERT to prevent the spread of COVID-19. However, many teacher educators are not ready yet to adapt to abrupt changes. They have a lack of knowledge, skills, and time to operate a variety of instructional platforms. Therefore, Sun (2011) points out that ERT offers flexibility in both place and time, but many teacher educators cannot work with a fixed timeframe required by the virtual classrooms. Also, Compton (2009) confirms that they are mostly familiar only with hardware and software and it is not enough to teach virtually. In other words, many teacher educators are still accustomed to conventional instructional practices and are not yet fully familiar with virtual-based instructions. To be able to design pedagogical strategies in an effective virtual classroom, they have to possess at least the ability to build an online environment that is different from that of a face-to-face classroom environment. Besides, teacher educators are supposed to have an adequate ability to facilitate preservice language teachers to build their communicative competence by reiterating the value of "task design" and "tutor intervention" and see that as the ways to achieve "online interaction" (Sun, 2011). This advocates that teacher educators need to receive ample supports from the university in the form of training. However, it seems that this training does not bring many changes to the performance of the teacher educators because the training is typically carried out in a short time and are given to the restricted personnel. Hence, Hodges et al (2020) point out that due to a narrow preparation window, the universities will not be able to offer the same level of supports to all teacher educators in the present situation. Thus, the training needs to be carefully designed and planned within sufficient time for many more personnel to have a significant impact on the performance of teacher educators.

The instructional platform is an important aspect that affects the success of ERT-based instruction, both synchronously and asynchronously. To support effective ERT-based instructions, teacher educators have to select a platform that suits for the pre-service language teachers' needs so they can interact and engage effectively. Furthermore, Wang and Chen (2009) underline that synchronous oral and visual interaction is a crucial component in virtual language learning, and fostering real-time synchronous interaction is an important principle in distance language teaching. The instructional platforms are supposed to facilitate the pre-service language teachers and the teacher educators to interact and engage simultaneously and effectively amid the COVID-19 pandemic. Therefore, Sun (2020) asserts that the platforms to support ERT-based instruction are supposed to provide the students and teachers the entire network that simultaneously holds multi-level interactions amongst its members: one-to-one, one-to-many, or many-to-many. Since interaction and engagement are two important principles for the success of virtual-based instruction, teachers have to opt for which platform is under the students' needs to make these two things happen.

The existing ERT-based instructional practice follows the flipped classroom approach. It refers to an instructional model that minimizes direct instructions by the teacher; the students are firstly supposed to learn the course contents at home; and the instructional activities are mostly in the form of assignments and discussion on the particular course contents. This model of instruction is beneficial to encourage pre-service language teachers to engage effectively and efficiently during the class (Turan \& Akdag-Cimen, 2020). Most of the pre-service language teachers become more autonomous and independent (Santikarn \& Wichadee, 2018) as they are motivated to discuss the course contents that are substantial or even to broaden the scope of the course contents they are supposed to master. Therefore, Murillo-Zamorano et al (2019) point out that there are four fundamental benefits the flipped classroom could present for successful instructions in the 21 st century, i.e. the instructional practices will be more interesting; time efficiency; students will be more independent; and the instruction will be more effective. The instructional process becomes more interesting because of the use of various instructional media, such as videos or digital applications. Student teachers will enjoy the learning process more while absorbing the materials provided. Due to the course contents provided before the class, it is clear that time efficiency will occur. The pre-service language teachers can access the course contents via the instructional platforms with their smartphone or PC and those aim to streamline the instructional practices. 
The pre-service language teachers' engagements and interactions are the central and pivotal place in a successful instruction, whether it is online or ERT-based instruction. This is because building the skills, such as how to teach language skills and how to assess the students' learning outcome, requires constant synchronous and asynchronous interaction with their teacher educator and peers (Martin \& Parker, 2014; Sun, 2011). The pre-service language teachers and their teacher educators are supposed to throw themselves enthusiastically into the virtual learning communities who are working hard to bring about effective ERTbased instructions amid the COVID-19 pandemic. Furthermore, Wang and Chen (2009) emphasize that synchronous and asynchronous oral and visual interactions and engagements are of great importance in ERTbased instructions. The real-time synchronous interactions and a wide variety of asynchronous engagements are important principles in distance language teaching.

It is, however, in our case, ERT-based instructions do not always work out well. There are at least two prominent challenges that need to address so that ERT becomes an effective instructional model amid the COVID-19 pandemic. Firstly, teacher educators have to possess the skills to teach and manage the class effectively in a virtual classroom. That is why Guichon (2010) stresses that the pressure provided by synchronous communication and the technical failings of the videoconferencing platform make ERT-based instructions more complex to carry out. This implies that teacher educators are supposed to learn how to coordinate their pedagogical strategy by utilizing the available instructional platforms and to rethink their pedagogical strategy to make it appropriate to apply in their virtual classrooms. Secondly, ERT-based instruction which is implemented synchronously and asynchronously requires the simultaneous presence of the pre-service language teachers. However, the pre-service language teachers who are initially enthusiastic about participating in the entire instructional practices and enjoy the flexibility in both place and time which ERT-based instruction offers, many of them ultimately lack discipline in taking the classes. Even, Sun (2011) reports that it is especially true that many of them are unable to work with the fixed length of time required by virtual classrooms. This condition can be beyond the teacher educator's control because he cannot provide all of his time and energy for everyone on various occasions.

\section{CONCLUSION}

For the context of the current study, the instructions are initially designed for the traditional, face-to-facebased model. Due to the COVID-19 pandemic, the instructional practices were then sifted to emergency remote teaching. ERT-based instruction is laudable as a successful instructional mode for overcoming the suspension of face-to-face instructions. However, the shift to ERT requires the teacher educators to take more control over their pedagogical strategy and its implementation. Due to the rapid shifts from traditional instruction to ERT, numerous teacher educators in need of support, and the university must find some ways to meet the institutional need to provide the continuity of instructions amid the COVID-19 pandemic. Although ERT has been successful in replacing the conventional face-to-face instructions and the pre-service language teachers generally have a positive view of it, there are also the challenges that occasionally result in ERT does not work well. The challenges come from two parties, both the teacher educator and the preservice teachers. The teacher educator has to possess the skills to teach and manage the class effectively in a virtual classroom. However, many of them have a lack of knowledge of virtual instructions and what learning management system (LMS) is supposed to use. On other hand, some of the pre-service language teachers have a lack of self-discipline to engage and interact virtually during the class and the teacher educator occasionally has limited control over such students. Whatever the challenges, the instructional practices are dynamic and must adjust to the demands in force at that time. It is recommended that teacher educators are supposed to find out the effective instructional strategies to cope with students' negative learning attitudes and to ensure that ERT-based instructions are effective for achieving the learning objectives. 


\section{BIODATA and CONTACT ADDRESSES of AUTHORS}

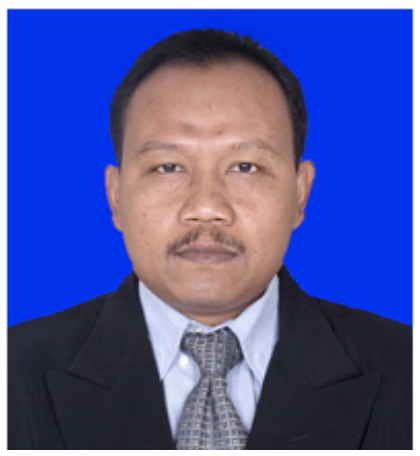

Dr. Sumardi SUMARDI is currently a faculty member at Teacher Training and Education Faculty, Universitas Sebelas Maret. He has been teaching English as a foreign language (EFL) since 1998. Dr. Sumardi gained his Ph.D. in Educational Research and Evaluation at October, 2011. His academic interest areas are in Language Assessment, Methodology in EFL, and Teacher Professional Development. He has over than 30 journal articles published in international indexes, 2 national books and other national and international articles, and papers submitted to international meetings.

Sumardi SUMARDI

English Education Department, Faculty of Teacher Training and Education

Address: Universitas Sebelas Maret, Jl. Ir. Sutami No.36, Postal Code 57126, Surakarta, Indonesia

Phone: +62 81329017845

E-mail: sumardi74@staff.uns.ac.id

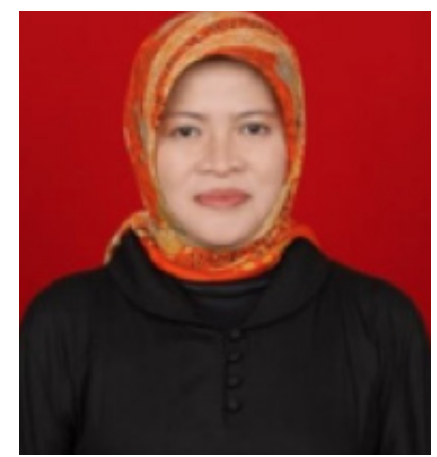

Dr. Dyah NUGRAHANI is currently a faculty member at Faculty of Language and Arts Education, Universitas PGRI Semarang. She has been teaching English as a foreign language (EFL) since 1998. Dr. Dyah Nugrahani gained her Doctoral degree in Linguistics at July, 2019. Her academic interests are in Teaching EFL and Translation. She has some journal articles published in international and national indexes; and papers submitted to international meetings.

Dyah NUGRAHANI

English Education Department, Faculty of Language and Arts Education

Address: Univesitas PGRI Semarang, Jl. Sidodadi Timur N0. 24 - Dr. Cipto, Postal Code 50124,

Semarang, Indonesia

Phone: +62 81575452718

E-mail: dyahnugrahani98@gmail.com

\section{REFERENCES}

Affouneh, S., Salha, S., \& Khlaif, Z. N. (2020). Designing Quality E-Learning Environments for Emergency Remote Teaching in Coronavirus Crisis. Interdisciplinary Journal of Virtual Learning in Medical Sciences, 11(2), 1-3. https://doi.org/ 10.30476/ijvlms.2020.86120.1033

Allo, M. D. G. (2020). Is online learning good in the midst of COVID-19 pandemic?: The case of EFL learners. Jurnal Sinestesia, 10(1), 1 - 10.

Alvara Research Center (2020). Disurvei, mayoritas ortu belum setuju, [Surveyed, majority of parents disagreed], Jawa Pos, July 13, 2020.

Andrade, M. S. (2015). Teaching online: a theory-based approach to student success. Journal of Education and Training Studies, 3(5), 2324 - 8068. https://doi.org/10.11114/jets.v3i5.904

Ary, D., Jacobs, L.C \& Sorensen, C. 2010. Introduction to Research in Education. Eight Edition. United States of America: Wadsworth 
Atmojo, A. E. P., \& Nugroho, A. (2020). EFL classes must go online! Teaching activities and challenges during the COVID-19 pandemic in Indonesia. Register Journal, 13(1), 49 - 76. https://doi.org/ 10.18326/rgt.v13i1.49-76

Bozkurt, A., \& Sharma, R. C. (2020). Emergency remote teaching in a time of global crisis due to the CoronaVirus pandemic. Asian Journal of Distance Education, 15(1), i-vi. https://doi.org/10.5281/ zenodo.3778083.

Cakrawati, L. M. (2017). Students' perceptions of the use of online learning platforms in the EFL classroom. English Language Teaching and Technology Journal (ELT-Tech Journal), 1(1), 22 - 30. https://doi. org/10.17509/elt\%20tech.v1i1.9428

Chambers, A. (2005). Integrating corpus consultation in language studies. Language Learning and Technology, 9(2), 111-125. http://dx.doi.org/10125/44022

Compton, L. K. L. (2009). Preparing language teachers to teach language online: a look at skills, roles, and responsibilities. Computer Assisted Language Learning, 22(1), 73 - 98. htttps://doi. org/10.1080/09588220802613831

Guichon, N. (2009). Training future language teachers to develop online tutors ${ }^{\mathrm{ee}}$ competence through reflective analysis. ReCall European Association for Computer Assisted Language Learning, 21(2), 166-185. https://doi.org/10.1017/S0958344009000214

Hampel, R., \& Stickler, U. (2005). New skills for the new classroom: Training tutors to teach languages online. Computer Assisted Language Learning, 18(4), 311 - 326. https://doi. org/10.1080/09588220500335455

Hodges, C., Moore, S., Lockee, B., Trust, T., \& Bond, A. (2020). The difference between emergency remote teaching and online learning. Retrieved August 12, 2020, from https://er.educause.edu/ articles/2020/3/the-difference-between-emergency-remote-teaching-and-online-learning.

Kruk, M. (2014). The use of internet resources and browser-based virtual worlds in teaching grammar. Teaching English with Technology, 14(2), 52 - 67.

Manfuso, L. G. (2020). From Emergency Remote Teaching to Rigorous Online Learning. Retrieved August 10, 2020, from https://edtechmagazine.com/higher/article/2020/05/emergency-remote-teachingrigorous-online-learning-perfcon.

Martin, F. \& Parker, M. A. (2014). Use of synchronous virtual classroom: why, who, and how? MERLOT Journal of Online Learning and Teaching, 10(2), $192-210$.

McMillan, James H. (2008). Educational Research: Fundamental for the Consumer. Fifth Edition. United States of America: Pearson Education, Inc.

Miles, M., Huberman, A. M., \& Saldana, J. (2014). Qualitative data analysis: A methods sourcebook ( $3^{\text {rd }}$ Ed.). Los Angeles: Sage Publications.

Ministry of Education and Culture. (2020). Belajar dari rumah, satuan pendidikan dapat pilih platform pembelajaran jarak jauh (Study from home, educational units can choose a distance learning platforms). Retrieved July 21, 2020 from https://www.kemdikbud.go.id/main/blog/2020/04/ belajar-dari-rumah-satuan-pendidikan-dapat-pilih-platform-pembelajaran-jarak-jauh-sesuaikebutuhan.

Moorhouse, B. L. (2020a). Adaptation to face-to-face initial teacher education course 'forced' online due to the COVID-19 pandemic. Journal of Education for Teaching. 1 - 3. https://doi.org/10.1080/026 07476.2020 .1755205

Moorhouse, B. L. (2020b). How English language teachers adapted to teaching on-line during covid-19: reconceptualizing face-to-face teaching for the digital space.

https://eteachers.online/how-english-language-teachers-adapted-to-teaching-online-duringcovid-19-reconceptualizing-face-to-face-teaching-for-the-digital-space/ 
Murillo-Zamorano, L. R., SAnchez, J. A. L., \& Godoy-Caballero, A. L. (2019). How the flipped classroom affects knowledge, skills, and engagement in higher education: Effects on students' satisfaction. Computers \& Education, 141(2019), 1 - 18. https://doi.org/10.1016/j.compedu.2019.103608.

Orlich, D. C., Harder, R. J., Callahan, R. C., Trevisan, M. S., \& Brown, A. H. (2010). Teaching strategies: a guide to effective instruction. Boston: Wadsworth, Cengage Learning.

Palmer, S., \& Holt, D. (2009) Staff and student perceptions of an online learning environment: Difference and development. Australasian Journal of Educational Technology, 25(3), 366-381. https://doi. org/10.14742/ajet.1140

Richards, J. C., \& Rodgers, T. S. (2001). Approaches and methods in language teaching. USA: Cambridge University Press.

Santikarn, B. \& Wichadee, S. (2018). Flipping the Classroom for English Language Learners: A Study of Learning Performance and Perception. International Journal of Emerging Technologies in Learning, 13(9), 123 - 135. https://doi.org/10.3991/ijet.v13i09.7792

Shisley, S. (2020). Emergency Remote Learning Compared to Online Learning. Retrieved from https:// learningsolutionsmag.com/articles/emergency-remote-learning-compared-to-online-learning.

Sun, S. Y. H. (2011). Online Language Teaching: the Pedagogical Challenges. Knowledge Management \& E-Learning: An International Journal, 3 (3), 428 - 447. https://doi.org/10.34105/j. kmel.2011.03.030.

Talidong, K. J. B. (2020). Implementation of emergency remote teaching (ERT) among Philippine teachers in Xi'an, China. Asian Journal of Distance Education, 15(1), 196-201. https://doi.org/10.5281/ zenodo.3881825

The Indonesian COVID-19 Task Force (2020). Perkembangan kasus terkonfirmasi positif COVID-19 per-hari [The development of positive confirmed cases of COVID-19 per day]. Retrieved July 23, 2020 from https://covid19.go.id/peta-sebaran.

Turan, Z. \& Akdag-Cimen, B. (2020) Flipped classroom in English language teaching: a systematic review. Computer Assisted Language Learning, 33(5-6), 590-606. https://doi.org/10.1080/09588221.201 9.1584117

Wang, Y., \& Chen, N.-S. (2009). Criteria for evaluating synchronous learning management system: arguments from the distance language classroom. Computer Assisted Language Learning, 22(1), 1-18. https://doi.org/10.1080/09588220802613773

Wong, K.M., \& Moorhouse, B.L. (2020): The Impact of Social Uncertainty, Protests, and COVID-19 on Hong Kong Teachers. Journal of Loss and Trauma, 25(8), 649-655. https://doi.org/10.1080/1532 5024.2020.1776523

Zuniga, A.T. (2020). Taking English learning online. Retrieved August 21, 2020, from https://www. languagemagazine.com/2020/06/22/taking-english-learning-online/ 